\title{
Effects of the polychaetes Arenicola marina and Nereis diversicolor on microbial pyrene mineralization
}

\author{
Karen Timmermann ${ }^{1,4, *}$, Gary T. Banta ${ }^{2}$, Anders R. Johnsen ${ }^{3}$, Ole Andersen ${ }^{4}$ \\ ${ }^{1}$ Department of Marine Ecology, National Environmental Research Institute, University of Aarhus, Frederiksborgvej 399, \\ PO Box 358, 4000 Roskilde, Denmark \\ ${ }^{2}$ Department of Environmental, Social and Spatial Change, Roskilde University, PO Box 260, 4000 Roskilde, Denmark \\ ${ }^{3}$ Department of Geochemistry, Geological Survey of Denmark and Greenland, 1350 Copenhagen K, Denmark \\ ${ }^{4}$ Department of Science, Systems and Models, Roskilde University, PO Box 260, 4000 Roskilde, Denmark
}

\begin{abstract}
The effects of 2 polychaetes, Nereis diversicolor and Arenicola marina, on the microbial mineralization of the organic contaminant pyrene, a polycyclic aromatic hydrocarbon (PAH), were followed over $44 \mathrm{~d}$. We also examined whether the effect of the polychaetes was caused by enhanced oxygen supply, altered pyrene bioavailability and/or a changed abundance or activity of pyrenedegrading bacteria. The presence of polychaetes enhanced microbial pyrene mineralization by 180 to $200 \%$ compared with defaunated sediment. Collectively, the replicates of the different treatments showed that mineralization rates were positively correlated with the amount of oxidized sediment, which comprised mainly the $3 \mathrm{~mm}$ surface layer and zones around burrows (burrow sediment). The biogenic sediment structures had similar mineralization potential and abundance of pyrene-degrading bacteria as surface sediments. Pyrene mineralization potential in bulk (reduced and presumably anoxic) sediment was significantly lower than for surface and burrow sediments. However, when the bulk sediments were oxidized, mineralization rates increased rapidly. Collectively, these data indicate that oxygen availability controlled pyrene mineralization in these experiments. On the other hand, the presence of the polychaetes significantly reduced the bioavailability of pyrene to the microbial degraders. Pyrene bioavailability in burrow sediment was always lower than the bioavailability in both surface and bulk sediments. In addition, $N$. diversicolor and especially $A$. marina decreased the bioavailability of pyrene in surface sediments compared with that of surface sediments in the non-bioturbated control. In conclusion, these polychaetes enhanced microbial pyrene mineralization significantly and this enhancement seemed to be caused by the increased oxygen supply due to burrow construction and irrigation. In contrast, these worms decreased pyrene bioavailability and, hence, counteracted to some extent the stimulating effect of irrigation.
\end{abstract}

KEY WORDS: Oxygen $\cdot$ Bioavailability $\cdot \mathrm{PAH} \cdot$ Biogenic structures $\cdot$ Bioturbation $\cdot$ Mineralization potential $\cdot$ MPN

Resale or republication not permitted without written consent of the publisher

\section{INTRODUCTION}

Polycyclic aromatic hydrocarbons (PAHs) are toxic and often also carcinogenic organic contaminants that enter the marine environment by incomplete combustion of fuels, industrial pyrolysis, or spills of crude oils and refined products. The PAHs are readily accumu- lated in marine sediments due to high hydrophobicity and very low degradation rates. Microbial mineralization of PAHs is considered the most important process leading to $\mathrm{PAH}$ decontamination and permanent removal from the environment (Neff 2002). PAHdegrading bacteria are present in most PAH-polluted environments although in very different numbers 
depending on factors such as pollution history (Johnsen \& Karlson 2005), redox status and nutrient availability (Carmichael \& Pfaender 1997, Joner et al. 2002).

Oxygen is a key variable for microbial PAH degradation and mineralization, determining both the degradation rate (McNally et al. 1999, Lei et al. 2005), pathway (Meckenstock et al. 2004) and the composition of bacteria involved in PAH degradation (Roslev et al. 1998, Eriksson et al. 2003). In general, aerobic PAH degradation is orders of magnitude higher than degradation under both nitrate- and sulphate-reducing conditions (Coates et al. 1997, Rockne \& Strand 1998). PAH degradation may also be limited by the low bioavailability. The amount, quality and diagenetic status of the sediment organic matter is known to affect PAH dissolution rates (Huang \& Weber 1997, Kukkonen et al. 2003) and, hence, the bioavailability of PAHs (Bosma et al. 1997, Johnsen et al. 2005).

Bioturbating infauna influence the availability of oxygen by their burrow construction and irrigation, which extends the sediment-water interface and oxidizes sediments at depth (e.g. Wenzhofer \& Glud 2004, Timmermann et al. 2006), allowing aerobic processes to occur in otherwise reduced sediments (Nielsen et al. 2004). Irrigated burrows often show enhanced activity of biogeochemical processes (Kristensen et al. 1985, Mayer et al. 1995, Papaspyrou et al. 2006) and both bacteria and meiofauna are often more abundant in burrows and tubes compared with the surrounding sediment (Reise 1981, Papaspyrou et al. 2006). The significance of burrow structures as sites of enhanced capacity for microbial PAH mineralization have also been documented (Chung \& King 1999, 2001, Granberg et al. 2005).

The stimulating effect of sediment-dwelling infauna on microbial processes and abundance is well recognised (Kristensen 2000). The few studies examining the effects of macrobenthos on total microbial PAH mineralization indicate that this stimulation also applies to $\mathrm{PAH}$ degradation (Bauer et al. 1988, McElroy et al. 1990, Christensen et al. 2002). However, decreased PAH degradation in the presence of polychaetes has also been observed due to transport of PAH-containing material from the surface into deeper anoxic zones (Kure \& Forbes 1997, Banta \& Andersen 2003).

The aim of the present study was to examine the effect of 2 common polychaetes, Arenicola marina and Nereis diversicolor, on the microbial mineralization of the tetracyclic model PAH pyrene in sediment, and furthermore, to determine whether an observed effect was caused by increased oxygen availability, changed microbial pyrene bioavailability, changed activity or abundance of pyrene degraders, or combinations of these factors.

\section{MATERIALS AND METHODS}

The experiment was conducted in 3 steps: (1) a preexposure phase where pyrene contaminated sediment was incubated for $25 \mathrm{~d}$ to allow growth of pyrene degraders, (2) an exposure phase and (3) an incubation phase. During the exposure phase, sediment was exposed to different treatments (see Table 1) consisting of sediment contaminated with either pyrene $(+)$ or ${ }^{14} \mathrm{C}$-pyrene $(++)$ combined with the addition of either Arenicola marina $(\mathrm{Am})$ or Nereis diversicolor $(\mathrm{Nd})$, or no fauna (C). During the exposure phase, ${ }^{14} \mathrm{CO}_{2}$ production was measured in treatments containing ${ }^{14} \mathrm{C}$ pyrene. After the exposure phase, sediment samples were collected from surface, burrow and bulk sediment from each treatment and transferred to ${ }^{14} \mathrm{C}$ respirometric flasks. Sediment samples originating from non-radioactive pyrene treatments were incubated with freshly added ${ }^{14} \mathrm{C}$-pyrene to measure the microbial pyrene mineralization potential, whereas sediment samples originating from treatments with ${ }^{14} \mathrm{C}$-pyrene were incubated with an inoculum of known pyrene degraders to measure the bioavailabilty of pyrene in the different sediment compartments.

Collection of sediment and polychaetes. Sediment and polychaetes were collected at a pristine, nearcoastal sandflat in Roskilde Fjord, Denmark $\left(55^{\circ} 41^{\prime} 51.9^{\prime \prime} \mathrm{N}, 12^{\circ} 5^{\prime} 47.4^{\prime \prime} \mathrm{E}\right)$. The fjord is brackish and, at the time of sampling, salinity was measured as $13 \%$. The water depth at the sampling site was $0.3 \mathrm{~m}$ during sample collection, but varied between 0 and $1.5 \mathrm{~m}$ depending on wind speed and direction. Sediment was collected in March from the top $10 \mathrm{~cm}$ of the seafloor, sieved $(1 \mathrm{~mm})$ in situ to remove stones and macrofauna, and frozen for $1 \mathrm{wk}$ to kill meiofauna and juvenile macrofauna. The sediment was characterised as fine to medium sand (dominated by 125 to $500 \mu \mathrm{m}$ grain size; data not shown) with a mean porosity of 0.35 and an organic matter content of $\sim 1.5 \%$. Polychaetes were collected in April by digging and kept in aquaria with sediment and water from the sampling site until use.

Table 1. Exposure phase treatments. Microcosms contained sediment contaminated with either pyrene $(+)$ or pyrene and ${ }^{14} \mathrm{C}$-pyrene $(++)$. Total nominal pyrene concentration was $10 \mathrm{mg} \mathrm{kg}^{-1}$ in all treatments. Each microcosm contained either Arenicola marina (Am), Nereis diversicolor (Nd) or no fauna (control sediment, C). Four replicate microcosms were used in each treatment (i.e. $\mathrm{n}=4$ )

\begin{tabular}{|lcc|}
\hline & Pyrene & Pyrene $+{ }^{14} \mathrm{C}$-pyrene \\
\hline No fauna (control) & $\mathrm{C}+$ & $\mathrm{C}++$ \\
Arenicola marina & $\mathrm{Am}+$ & $\mathrm{Am}++$ \\
Nereis diversicolor & $\mathrm{Nd}+$ & $\mathrm{Nd}++$ \\
\hline
\end{tabular}


Sediment contamination. Contaminated sediment was prepared by mixing $(24 \mathrm{~h})$ wet sediment with pyrene dissolved in acetone to a final concentration of $20 \mathrm{mg} \mathrm{kg}^{-1}$. The contaminated sediment was then distributed in boxes in an approximately $1 \mathrm{~cm}$ layer covered with water that was continuously aerated with air stones. The boxes were incubated for $25 \mathrm{~d}$ at $12^{\circ} \mathrm{C}$.

After this pre-exposure phase, the pyrene contaminated sediment was further mixed $(24 \mathrm{~h})$ with clean sediment and either $\left[{ }^{14} \mathrm{C}-4,5,9,10\right]$-pyrene $(58.7 \mathrm{mCi}$ $\mathrm{mmol}^{-1}$, purity $>98 \%$, Sigma-Aldrich) or nonradioactive pyrene. The specific activity of the ${ }^{14} \mathrm{C}$-pyrenelabelled sediment was 5000 disintegrations per minute (dpm) $\mathrm{g}^{-1}$ and the total nominal concentration of pyrene was $10 \mathrm{mg} \mathrm{kg}^{-1}$ in all treatments.

Experimental set-up. The experiment was set up in polyacrylic core tubes. The dimensions of the core tubes used in treatments with Nereis diversicolor and controls (groups $\mathrm{Nd}$ and $\mathrm{C}$ ) were $5 \mathrm{~cm}$ in diameter $(\varnothing)$ and $30 \mathrm{~cm}$ high (l). These core tubes were filled with $1.3 \mathrm{~kg}$ of contaminated sediment after which $100 \mathrm{ml}$ of filtered $(0.2 \mu \mathrm{m})$ seawater, diluted with deionized water to a salinity of $15 \%$, was carefully added to each core. One $N$. diversicolor $(0.47 \pm 0.09 \mathrm{~g}$ wet weight [mean $\pm \mathrm{SD}]$ ) was added to each core in group $\mathrm{Nd}+$ and $\mathrm{Nd}++$, equivalent to a density of $\sim 500$ worms $\mathrm{m}^{-2}$. Larger core tubes $(\varnothing=8.2 \mathrm{~cm}, 1=40 \mathrm{~cm})$ were used for Arenicola marina (Am) due to greater space requirements needed for its feeding strategy and lower natural density. These core tubes were filled with $3.2 \mathrm{~kg}$ of contaminated sediment overlaid by $250 \mathrm{ml}$ of filtered seawater. One A. marina $(1.7 \pm 0.5 \mathrm{~g}$ wet weight) was added to each core, equivalent to a density of $\sim 190$ worms $\mathrm{m}^{-2}$. Worms that failed to burrow within $15 \mathrm{~min}$ were replaced. The cores were incubated for $44 \mathrm{~d}$ at $12^{\circ} \mathrm{C}$ in the dark to prevent photo-oxidation of pyrene and photoautotroph fixation of ${ }^{14} \mathrm{CO}_{2}$ (produced during microbial ${ }^{14} \mathrm{C}$-pyrene mineralization).

To trap ${ }^{14} \mathrm{CO}_{2}$, cores with ${ }^{14} \mathrm{C}$-pyrene contaminated sediment (i.e. groups $\mathrm{C}++, \mathrm{Am}++, \mathrm{Nd}++$ ) were sealed with rubber stoppers, and out-flowing air was passed through 2 serially connected $\mathrm{CO}_{2}$ traps consisting of gas-wash bottles each containing $10 \mathrm{ml}$ of $0.5 \mathrm{M}$ $\mathrm{NaOH}$. Trap efficiency was $>92 \%$ (tested with ${ }^{14} \mathrm{C}$ $\mathrm{NaHCO}_{3}$ ). Cores with non-radioactive pyrene were also sealed with stoppers, but the out-flowing air was not connected to $\mathrm{CO}_{2}$ traps.

The radioactivity in $\mathrm{CO}_{2}$ traps and overlying water was measured every 4 th day when the $\mathrm{CO}_{2}$ trapping tubes and overlying water was changed. Radioactivity in the $\mathrm{CO}_{2}$ traps was quantified by liquid scintillation counting on a Wallac LKB 1219 counter using $4 \mathrm{ml}$ of sample and $10 \mathrm{ml}$ Packard Ultima Gold XR. Radioactive $\mathrm{CO}_{2}$ in overlying water was measured before each water change by transferring $20 \mathrm{ml}$ of overlying water to a closed vessel containing a $\mathrm{CO}_{2}$ trap with $5 \mathrm{ml}$ of $0.5 \mathrm{M} \mathrm{NaOH}$. Water was acidified with $1 \mathrm{ml}$ of $1 \mathrm{M} \mathrm{HCl}$ and after $4 \mathrm{~h}, 4 \mathrm{ml} \mathrm{NaOH}$ from each trap was transferred to $10 \mathrm{ml}$ Packard Ultima Gold XR and the radioactivity from ${ }^{14} \mathrm{CO}_{2}$ was quantified.

Collection of surface, bulk and burrow sediment. After incubation, the cores were sectioned into different sediment pools containing surface sediment, anoxic bulk sediment, burrow sediment (only Am and Nd groups) and oxidized non-burrow sediment when observed. Surface sediment was collected by cutting off the top $3 \mathrm{~mm}$ of each sediment core. In all cores, this layer was completely oxidized. Burrow sediment was defined as the inner $2 \mathrm{~mm}$ of sediment lining the burrows and collected by carefully scraping the burrows with a spatula. When oxidized non-burrow sediment was observed during sectioning, that sediment was also collected. In the present study, oxidized sediment is defined by the light grey-brown colour (i.e. the presence of oxidized metals). Although oxygen is not necessarily present in oxidized sediments, oxidation of metal species is ultimately linked to molecular oxygen through a series of coupled oxidation-reduction reactions and we use oxidized sediment as an indicator of sediment that is continuously or periodically subjected to oxygen. Bulk sediment, which was almost black, was defined as reduced (and presumably anoxic) sediment.

Microbial pyrene mineralization potential. Pyrene mineralization potential was measured as the ability to mineralize freshly added ${ }^{14} \mathrm{C}$-pyrene under oxic conditions in surface, bulk and burrow sediment samples collected from treatments without radioactive pyrene $(\mathrm{C}+, \mathrm{Nd}+$ and $\mathrm{Am}+$ ). Sediment samples (3 to $5 \mathrm{~g}$ ) were transferred to Erlenmeyer flasks coated with ${ }^{14} \mathrm{C}$ pyrene $(0.07 \mu \mathrm{g}, 0.02 \mu \mathrm{Ci})$ and $5 \mathrm{ml}$ of seawater was added. The sediment slurries were incubated on an orbital shaker (60 revolutions [rev.] $\mathrm{min}^{-1}$ ) in the dark for $99 \mathrm{~d}$. The ${ }^{14} \mathrm{CO}_{2}$ produced was collected in $5 \mathrm{ml}$ of $0.5 \mathrm{M} \mathrm{NaOH}$ contained in $6 \mathrm{ml}$ plastic vials suspended from the silicone stoppers and quantified by mixing $4 \mathrm{ml}$ of the $\mathrm{NaOH}$ with $6 \mathrm{ml}$ of Ultima Gold scintillation cocktail and counted. Trapping efficiency of the incubation system was $>95 \%$ (tested with ${ }^{14} \mathrm{C}-\mathrm{NaHCO}_{3}$ ).

Microbial pyrene bioavailability. The bioavailability of ${ }^{14} \mathrm{C}$-pyrene aged during the exposure phase (44 d) was measured in surface, burrow and bulk sediment samples from treatments $\mathrm{C}++, \mathrm{Nd}++$ and $\mathrm{Am}++$ using the set-up described for mineralization potential with the following changes. Non-coated Erlenmeyer flasks with sample material were inoculated with 2 bacterial pyrene degraders (DSM 44346: Mycobacterium frederiksbergense Fan9 and DSM 7251: Мycobacterium vanbaalenii PYR-1; $10^{5}$ and $10^{7} \mathrm{CFU}$ [colony forming units] $\mathrm{g}^{-1}$ sediment, respectively) so that 
pyrene bioavailability, and neither pyrene degradation capacity nor oxygen, was the limiting factor for pyrene mineralization. The inoculum was grown in LuriaBertani (LB) medium and washed twice in $\mathrm{MgSO}_{4}$ (50 $\mathrm{mM}$ ) before addition to the sediment.

Bioavailability was measured both as the flux of pyrene from the sediment into the bacteria and as the amount of bioaccessible pyrene, i.e the total amount of pyrene that becomes bioavailable over time (Reichenberg \& Mayer 2006). The flux of bioavailable pyrene was estimated as the mineralization rate of aged ${ }^{14} \mathrm{C}$ pyrene immediately after the addition of the pyrene degraders, whereas the total amount of bioavailable pyrene (bioaccessibility) was determined as the total cumulative ${ }^{14} \mathrm{CO}_{2}$ production at the end of the incubation period.

Microbial populations. The most probable number (MPN) of aerobic bacteria growing on pyrene in surface and burrow sediments was determined using a microplate method based on the respiration indicator WST-1 (Johnsen et al. 2002) modified for marine conditions. In short, microbial cells were extracted from $5 \mathrm{~g}$ (wet weight) of sediment with $45 \mathrm{ml}$ of pyrophosphate buffer (1.2 mM tetrasodium pyrophosphate, $\mathrm{pH} 7.0$, salinity $15 \%$ ). The sediment-buffer suspension was shaken for 10 min, after which a 3 -fold dilution series was made in phosphate minimal medium (Johnsen et al. 2002) adjusted to a salinity of $15 \%$. A dilution of 1:270 of the sediment was used as the lowest dilution, giving a detection limit of 150 pyrene degraders $\mathrm{g}^{-1}$. The pyrene was dissolved in hexane, added to the wells and the hexane was allowed to evaporate leaving the microplate wells coated with crystalline pyrene. Six replicates (200 $\mu$ l each) of sediment-buffer suspension dilution were transferred to the wells. Pyrene was added as the sole source of carbon and energy to the wells. Therefore, positive growth in the wells was attributed to bacteria-degrading pyrene. Negative control plates (with no carbon or energy source) were treated with the hexane solvent only. The plates were incubated for $4 \mathrm{wk}$ in a fume hood at approximately $20^{\circ} \mathrm{C}$. To test the wells for growth, the potential respiration of each well was assayed by adding a carbon mixture (glucose, succinate and pyruvate) and Cell Proliferation Reagent WST-1 (Roche Molecular Biochemicals). The respiratory reduction of WST-1 (absorbance at $450 \mathrm{~nm}$ with a reference wavelength at $630 \mathrm{~nm}$ ) was measured at time zero and after $6 \mathrm{~h}$ incubation on an orbital shaker (300 rev. $\mathrm{min}^{-1}$ ) at room temperature. Wells were considered positive (i.e. microbial growth on pyrene) when the absorbance change was higher than 0.020 compared with the initial absorbance. The absorbance change in negative control plates was always much less than 0.020 .

MPN estimates were calculated using the DOS program 'MPN Calculator' version 2.70 (Klee 1993). Neg- ative wells at low dilutions were considered false negatives when all wells were positive in one or more following dilutions. The total bacterial population that was culturable was determined as the number of heterotrophic colony forming units (CFU) by plating 10-fold serial dilutions on marine agar 2216 (Difco) followed by incubation at $22^{\circ} \mathrm{C}$ for $10 \mathrm{~d}$.

Statistical analysis. Rates of microbial pyrene mineralization, measured as ${ }^{14} \mathrm{CO}_{2}$ production, were calculated for each replicate using the slope of regression on the linear part of cumulative $\mathrm{CO}_{2}$ production versus time plots. Differences in calculated slope values were tested using ANOVA after assuring that the ANOVA assumptions (normal distribution of residuals and homogeneity of variances) were fulfilled. ANOVA main effects were further analysed using a post hoc Tukey's honest significant difference (HSD) test.

Total cumulative ${ }^{14} \mathrm{CO}_{2}$ production was defined as the last data point of the cumulative data sets. Differences in cumulative production were tested using ANOVA followed by the post hoc HSD test. The estimated MPNs of pyrene degraders in different sediment compartments were analysed using the nonparametric Kruskal-Wallis test, since the ANOVA assumptions were not fulfilled.

\section{RESULTS}

\section{Pyrene mineralization in microcosms}

Pyrene mineralization started at maximum rates in all microcosms (Fig. 1). Mineralization rates were nearly constant throughout the incubation period in the $\mathrm{Nd}++$

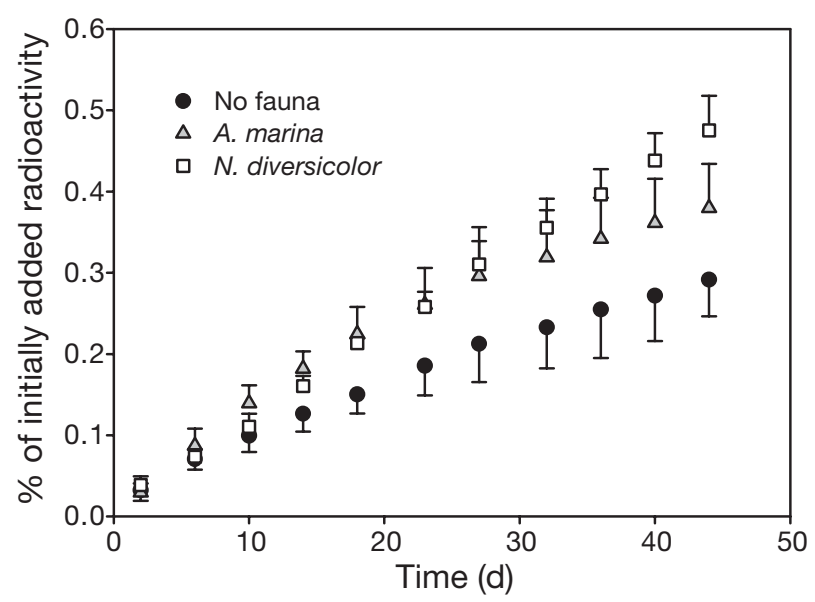

Fig. 1. Microbial ${ }^{14} \mathrm{C}$-pyrene mineralization measured as cumulative ${ }^{14} \mathrm{CO}_{2}$ production in microcosms containing either Arenicola marina, Nereis diversicolor or no fauna. Production of ${ }^{14} \mathrm{CO}_{2}$ is expressed as percent of the activity of the ${ }^{14} \mathrm{C}$ pyrene originally added to each microcosm. Each point represents 4 replicates. Error bars represent SD 
treatment, whereas mineralization rates in $\mathrm{C}++$ and especially in Am++ treatments decreased over time, resulting in a non-linear cumulative ${ }^{14} \mathrm{CO}_{2}$ production (Fig. 1). The maximum rate of pyrene degradation was estimated using linear regression performed on data from Days 2 to 23 (sampling every 4 to $5 \mathrm{~d}$ ), whereas total pyrene degradation was estimated as the cumulative ${ }^{14} \mathrm{CO}_{2}$ production at the end of the experiment (44 d).

The presence of macrofauna significantly enhanced the maximum rate of ${ }^{14} \mathrm{CO}_{2}$ production compared with control sediment by approximately $200 \%$ (Table 2). No difference was detected between macrofauna. After $44 \mathrm{~d}$, significant differences were detected in total cumulative ${ }^{14} \mathrm{CO}_{2}$ production (1-way ANOVA, $\mathrm{p}=0.007$ ). Total ${ }^{14} \mathrm{CO}_{2}$ production was higher in treatments with Nereis diversicolor compared with control sediment, whereas no significant difference was detected between sediment with Arenicola marina and control sediment or between the 2 polychaetes (Table 2).

At the end of the $44 \mathrm{~d}$ exposure phase, we determined the amount of oxidized sediment in all the replicates of the different treatments. The calculated pyrene mineralization rates in the different replicates are plotted against the amount of oxidized sediment (Fig. 2). Considering all the replicates of the different treatments collectively, Fig. 2 shows a strong link between the amount of oxidized sediment and the pyrene mineralization rate (positive correlation; $r=0.93, p<0.0001$ ) substantiating the strong dependence of pyrene mineralization on the availability of oxygen.

\section{Pyrene mineralization potential}

In all oxidized sediment samples (i.e. burrow and surface sediments), production of ${ }^{14} \mathrm{CO}_{2}$ started at maximum rates immediately after the addition of ${ }^{14} \mathrm{C}$ pyrene (Fig. 3). In samples with bulk (previously anoxic) sediment, the mineralization rates increased during the first 6 to $10 \mathrm{~d}$, indicating growth of microbial pyrene degraders.

Table 2. Pyrene mineralization rates $( \pm \mathrm{SD})$ and total cumulative pyrene mineralization in microcosms containing ${ }^{14} \mathrm{C}$-pyrene-contaminated sediment $(++)$ and either Arenicola marina (Am), Nereis diversicolor (Nd) or no fauna (C). ANOVA tests indicated significant differences in mineralization rates $(p=0.003)$ and total mineralization $(\mathrm{p}=0.007)$ among treatments. Significant differences between treatments detected by the post hoc Tukey's honest significant difference (HSD) test are indicated with capital letters

\begin{tabular}{|lcccc|}
\hline $\begin{array}{l}\text { Exposure phase } \\
\text { treatment }\end{array}$ & $\begin{array}{c}\text { Mineralization } \\
\text { rate }\left(\% \mathrm{~d}^{-1}\right)\end{array}$ & $\begin{array}{c}\text { Group } \\
(\text { HSD test) }\end{array}$ & $\begin{array}{c}\text { Total mineralization } \\
\text { after 44 d }(\%)\end{array}$ & $\begin{array}{c}\text { Group } \\
\text { (HSD test) }\end{array}$ \\
\hline $\mathrm{C}++$ & $0.0060 \pm 0.0012$ & $\mathrm{~A}$ & $0.29 \pm 0.05$ & $\mathrm{~A}$ \\
$\mathrm{Am}++$ & $0.0125 \pm 0.0024$ & $\mathrm{~B}$ & $0.38 \pm 0.05$ & $\mathrm{~A}, \mathrm{~B}$ \\
$\mathrm{Nd}++$ & $0.0109 \pm 0.0011$ & $\mathrm{~B}$ & $0.48 \pm 0.04$ & $\mathrm{~B}$ \\
\hline
\end{tabular}

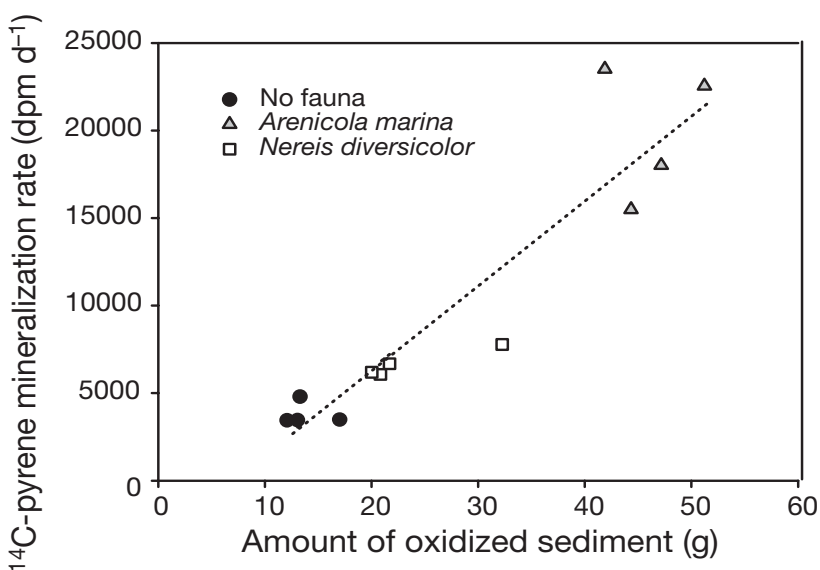

Fig. 2. Correlation between ${ }^{14} \mathrm{C}$-pyrene mineralization rates and the amount of oxidized sediment (mainly surface and burrow sediment) collected at the end of the exposure phase in microcosms containing either Arenicola marina, Nereis diversicolor or no fauna $(\mathrm{r}=0.93, \mathrm{p}<0.0001)$. dpm: disintegrations per minute

Pyrene mineralization potential, measured as the initial rate of ${ }^{14} \mathrm{CO}_{2}$ production, was equally high in oxidized sediments, regardless of origin (burrow and surface sediments) whereas significantly lower mineralization potentials were observed in bulk sediments ( $p<0.0001$, Table 3$)$. There was no apparent effect of fauna on degradation rates.

\section{Microbial populations}

The number of heterotrophic colony forming units (CFU) ranged from $1.2 \times 10^{6}$ to $7.6 \times 10^{7} \mathrm{CFU} \mathrm{g}^{-1}$ (Fig. 4) and no significant differences in CFU were detected between the different types of sediment ( $p>0.2)$. Aerobic bacteria growing on pyrene were detected in all the oxidized sediment samples (Fig. 4). The estimated number ranged from 150 cells $\mathrm{g}^{-1}$ detected in surface sediment to more than 20000 cells $\mathrm{g}^{-1}$ in burrow sediments of Arenicola marina and Nereis diversicolor; however, MPN estimates were highly variable within treatments. The average numbers of bacteria growing on pyrene in burrow sediments were 12000 (range: 6700 to 20000 ) cells g $^{-1}$ (A. marina) and 9670 (range: 3800 to $21000)$ cells $\mathrm{g}^{-1}$ ( $N$. diversicolor). In surface sediment, the estimated number was 1300 (range: 150 to 2800) cells $\mathrm{g}^{-1}$. These differences between burrow and surface sediments could not be confirmed to be statistically significant, however, according to a KruskalWallis test $(p=0.061)$. The contribu- 

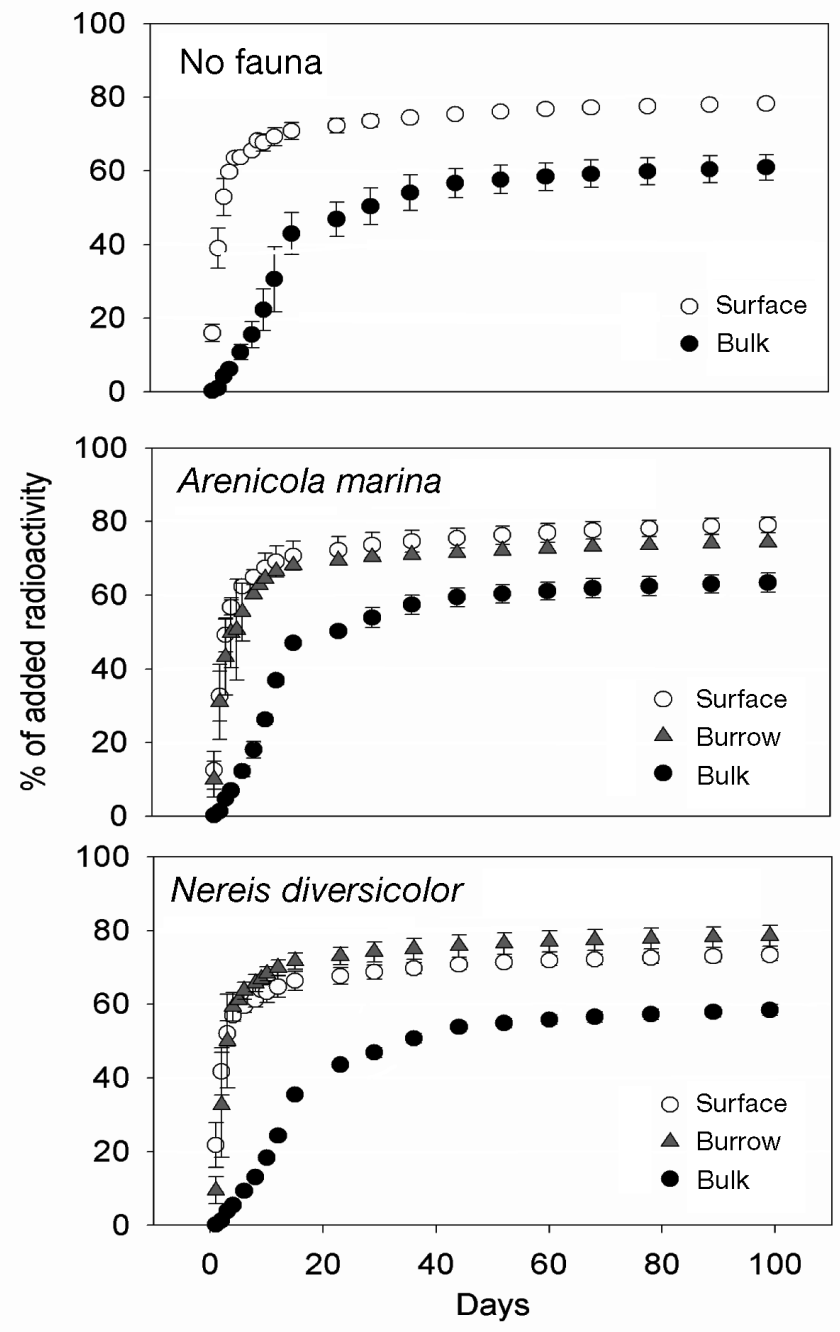

Fig. 3. Mineralization potential of ${ }^{14} \mathrm{C}$-pyrene of surface, burrow and bulk sediments measured as ${ }^{14} \mathrm{CO}_{2}$ production during oxic incubations. Cumulative ${ }^{14} \mathrm{CO}_{2}$ production is expressed as percent of the activity of the ${ }^{14} \mathrm{C}$-pyrene added to each incubation flask. Error bars represent SD

tion of bacteria able to grow solely on pyrene to the total number of (colony forming) bacteria was significantly higher (Kruskal-Wallis, p < 0.011) in burrow sediment from A. marina $(0.51 \pm 0.24 \%)$ compared with surface sediment $(0.036 \pm 0.03 \%)$ and $N$. diversicolor burrow sediment $(0.068 \pm 0.04 \%)$. Potential pyrene mineralization rates measured in the different sediment samples were significantly correlated with the estimated number of bacteria growing on pyrene $(\mathrm{p}=0.026, \mathrm{r}=0.64)$.

\section{Microbial pyrene bioavailability}

Pyrene bioavailability, determined as mineralization of ${ }^{14} \mathrm{C}$-pyrene, aged in the sediment for $44 \mathrm{~d}$ (Fig. 5), was significantly different among treatments (1-way ANOVA, p < 0.0001).

The initial mineralization rates (i.e. flux of bioavailable pyrene from sediment to bacteria) were higher in surface sediments compared with bulk and burrow sediments (Table 4). Furthermore, the pyrene flux in surface sediment was significantly inhibited by fauna, with the highest flux in surface sediments from control treatments, followed by surface sediments from $\mathrm{Nd}++$

Table 3. Pyrene mineralization potential $( \pm \mathrm{SD})$ measured as the ability to mineralize freshly added ${ }^{14} \mathrm{C}$-pyrene under oxic conditions in surface, burrow and bulk sediment. Sediment samples originate from exposure phase treatments with nonradioactive pyrene and with either Arenicola marina, Nereis diversicolor or no fauna. Prior to the incubation ${ }^{14} \mathrm{C}$-pyrene was added. An ANOVA test indicated that there were significant differences in mineralization potential among sediment types $(\mathrm{p}<0.0001)$. Significant differences between sediment types detected by the post hoc Tukey's HSD test are indicated with capital letters

\begin{tabular}{|lcc|}
\hline Treatment & $\begin{array}{c}\text { Pyrene mineralization } \\
\text { potential }\left(\% \mathrm{~d}^{-1}\right)\end{array}$ & $\begin{array}{c}\text { Group } \\
\text { (HSD test) }\end{array}$ \\
\hline $\mathbf{C +}$ & & \\
Surface & $14.47 \pm 0.66$ & $\mathrm{~A}$ \\
Bulk & $1.48 \pm 1.07$ & $\mathrm{~B}$ \\
Am+ & & \\
Surface & $14.91 \pm 1.29$ & $\mathrm{~A}$ \\
Burrow & $13.44 \pm 0.43$ & $\mathrm{~A}$ \\
Bulk & $2.34 \pm 0.96$ & $\mathrm{~B}$ \\
Nd+ & & $\mathrm{A}$ \\
Surface & $11.58 \pm 2.52$ & $\mathrm{~A}$ \\
Burrow & $16.67 \pm 0.48$ & $\mathrm{~B}$ \\
Bulk & $1.83 \pm 0.71$ & \\
\hline
\end{tabular}

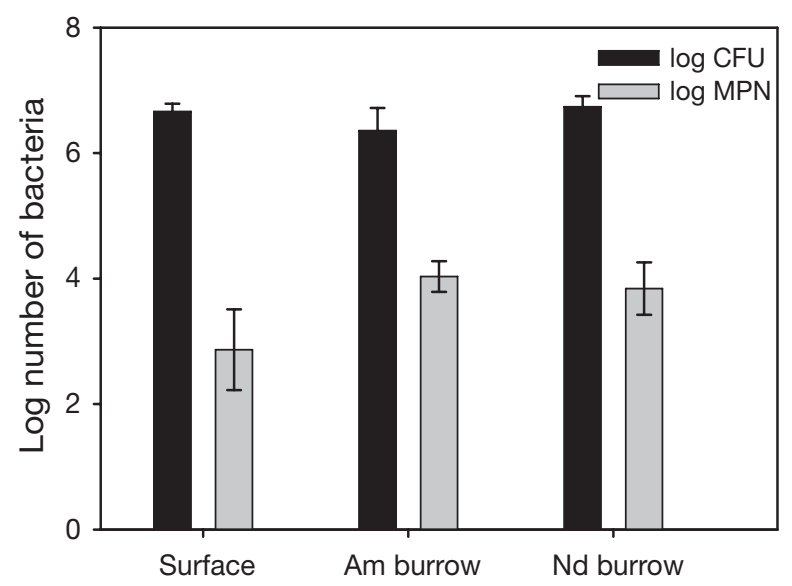

Fig. 4. Abundance of total culturable bacteria (as colony forming units, CFU) and most probable number (MPN) of bacteria growing on pyrene in surface sediment and sediment from burrows of Arenicola marina (Am) and Nereis diversicolor (Nd). Error bars represent SD 


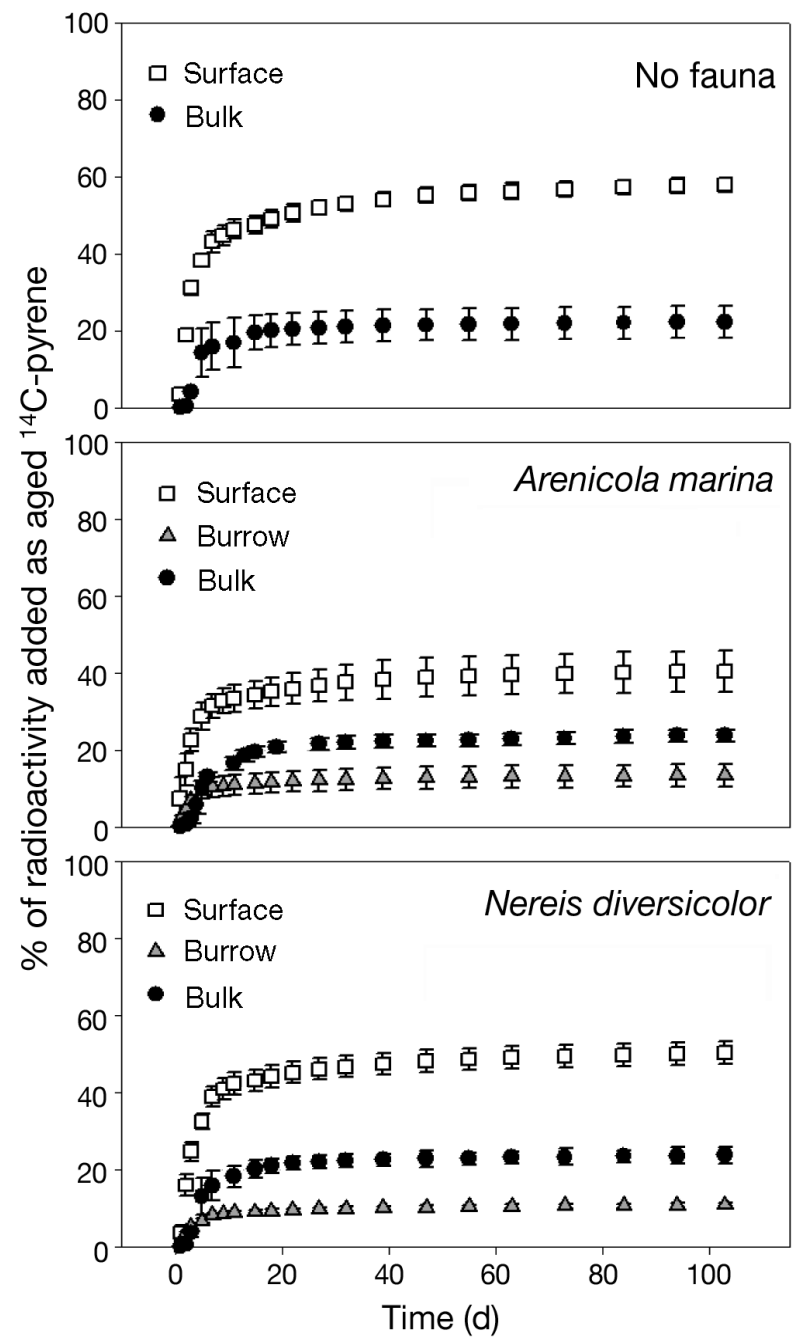

Fig. 5. Bioavailability of pyrene in surface, burrow and bulk sediment measured as mineralization of aged ${ }^{14} \mathrm{C}$-pyrenecontaminated sediment during oxic incubation with a pyrene degrading inoculum. Mineralization is expressed as cumulative ${ }^{14} \mathrm{CO}_{2}$ production in percent of the activity of the ${ }^{14} \mathrm{C}$-pyrene originally added to the sediment. Error bars represent $\mathrm{SD}$

and Am++ treatments. There were no significant differences in mineralization rates between bulk sediments and burrow sediments from the 2 polychaetes (Table 4).

The total bioavailable amount (bioaccessability) of the aged ${ }^{14} \mathrm{C}$-pyrene, determined as total cumulative ${ }^{14} \mathrm{CO}_{2}$ production, was also highest in surface sediments followed by sediments and burrow sediments (Fig 5). Pyrene bioaccessibility in surface sediment from treatment $\mathrm{C}++$ was significantly higher than in surface sediment from treatment $\mathrm{Am}++$, but not different from treatment $\mathrm{Nd}++$ (Table 4$)$. Contrary to the initial mineralization rates, bulk sediment showed a significantly higher total cumulative ${ }^{14} \mathrm{CO}_{2}$ production compared with sediments from burrows made by Nereis diversicolor (Table 4). No significant differences in bioaccessibility were detected between bulk sediment and burrow sediment from the Am++ treatment or between burrow sediment from the $\mathrm{Nd}++$ and Am++ treatments (Table 4).

\section{DISCUSSION}

The production of ${ }^{14} \mathrm{CO}_{2}$, indicative of ${ }^{14} \mathrm{C}$-pyrene mineralization, was enhanced approximately 2-fold in microcosms inhabited by polychaetes compared with defaunated sediment (Table 2). Although only a few studies have examined the effects of infauna on microbial PAH degradation, most of these show that the presence of infauna such as Nereis virens, Arenicola marina and Capitella sp. stimulate the degradation of various PAHs, and enhancement factors of between 2 and 3 have been reported (Bauer et al. 1988, McElroy et al. 1990, Christensen et al. 2002). In contrast, Kure \& Forbes (1997) observed decreased mineralization of fluoranthene in a sediment containing A. marina. In that case, however, the fluoranthene was added as a contaminated top layer that was rapidly buried into anoxic sediment due to the conveyor belt feeding behaviour of A. marina (Kure \& Forbes 1997). Our results are consistent with other sediment studies where the pollutants were uniformly distributed throughout the sediment.

Collectively, the replicates of the different treatments showed that mineralization rates were positively correlated with the amount of oxidized sediment (surface plus burrow sediment), which clearly supports the hypothesis that pyrene mineralization in microcosms is controlled by the availability of oxygen (Fig. 2). Furthermore, the increase of oxidized sediments due to the formation and irrigation of burrows is the main effect of macrofauna leading to the stimulation of microbial PAH mineralization. Oxygen has been shown to be the controlling factor for microbial $\mathrm{PAH}$ degradation in aquatic sediments (Boyd et al. 2005) as well as in low permeability soils and soil aggregates (Nocentini \& Pinelli 2001), and low oxygen availability, especially for the bulk sediment, was probably limiting for PAH mineralization in this study.

The fact that biogenic structures are important sites for microbial PAH mineralization is further confirmed by the high pyrene mineralization potential measured in sediment from both Arenicola marina and Nereis diversicolor burrows (Fig. 3, Table 3). Pyrene mineralization was significantly higher in burrows than in the ambient bulk sediment and equalled the high rates observed in surface sediments. Hence, pyrene mineralization in macrofauna burrows not only contribute to 
Table 4. Microbial pyrene bioavailability $( \pm \mathrm{SD})$ measured in surface, burrow and bulk sediment as the ability to mineralize ${ }^{14} \mathrm{C}$-pyrene (aged during the exposure phase) after addition of known pyrene degraders. Sediment samples originate from exposure phase treatments with radioactive pyrene and with either Arenicola marina, Nereis diversicolor or no fauna. Bioavailability was measured both as the flux of pyrene from the sediment to the bacteria and as bioaccessible pyrene, i.e. the total amount of bioavailable pyrene (see text). ANOVA tests indicated significant differences in the flux of bioavailable pyrene $(p<0.0001)$ and bioaccessible pyrene $(p<0.0001)$ among sediment types. Significant differences between sediment types detected by the post hoc Tukey's HSD test are indicated with capital letters

\begin{tabular}{|lcccc|}
\hline Treatment & $\begin{array}{c}\text { Flux of bio- } \\
\text { available pyrene } \\
\left(\% \mathrm{~d}^{-1}\right)\end{array}$ & $\begin{array}{c}\text { Group } \\
\text { (HSD test) }\end{array}$ & $\begin{array}{c}\text { Bioaccessible pyrene } \\
(\% \text { of added } \\
14 \text { C-pyrene })\end{array}$ & $\begin{array}{c}\text { Group } \\
\text { (HSD test) }\end{array}$ \\
\hline C++ & & & & \\
Surface & $8.4 \pm 0.3$ & A & $57.9 \pm 1.9$ & A \\
Bulk & $2.2 \pm 0.9$ & D & $22.3 \pm 4.2$ & C \\
Am++ & & & & B \\
Surface & $5.3 \pm 0.8$ & B & $40.5 \pm 5.3$ & C, D \\
Burrow & $1.8 \pm 0.5$ & D & $13.4 \pm 2.9$ & A \\
Bulk & $2.7 \pm 0.8$ & D & $23.8 \pm 2.2$ & D \\
Nd++ & & & & C \\
Surface & $7.0 \pm 0.3$ & C & $50.4 \pm 3.0$ & $10.8 \pm 0.6$ \\
Burrow & $1.4 \pm 0.1$ & D & $23.7 \pm 1.6$ & \\
Bulk & $2.5 \pm 0.6$ & D & & \\
\hline
\end{tabular}

pyrene biodegradation, but may be as efficient as in the surface sediment. Burrows may, thus, be considered extensions of the oxic surface layer with respect to pyrene degradation. These observations are in accordance with Chung \& King (1999) and Granberg et al. (2005), who also found that mineralization rates in burrow sediments were much higher than in the surrounding sediment, and in a few cases even higher than mineralization rates in surface sediment.

Aerobic bacteria able to grow solely on pyrene were found in burrow sediment from both polychaetes at the same or slightly higher abundances than in surface sediments (Fig. 4). However, the comparable density and activity of these pyrene-degrading bacteria found in burrow and surface sediments is somewhat surprising, however, considering the different physical and chemical conditions in these environments. The few studies where molecular oxygen was measured in macrofaunal burrow structures indicate that oxygen concentrations in burrows are lower than in sediment surfaces and the supply fluctuates due to the discontinuous irrigation (Forster \& Graf 1995, Timmermann et al. 2006). The similarities in pyrene degradation between burrow and surface sediments suggest that the oscillating oxygen concentration in ventilated burrows is sufficient to maintain a PAH-degrading capacity similar to the sediment surface with more constant oxygen concentrations. Since PAH degradation rates seem to depend on oxygen exposure time (Chung \& King 1999), the actual in situ mineralization rates are probably lower in burrows compared with surface sediments because oxygen is not always present in the burrow (Timmermann et al. 2006). Given the high potential for PAH mineralization in the burrows, we expect pyrene degradation to occur whenever oxygen is provided by ventilation.

The pyrene mineralization potential of bulk (anoxic) sediment was significantly lower than mineralization potential in burrow and surface sediments (Table 3). Although anaerobic degradation of low molecular weight PAHs ( $\leq 3$ fused benzene rings) has been observed under both nitrate- and sulphate-reducing conditions, anaerobic degradation rates are orders of magnitude lower than aerobic degradation (Coates et al. 1997, Rockne \& Strand 1998). Furthermore, the few cases where anaerobic degradation of high molecular weight PAHs, such as pyrene, have been reported were from sediment with a long history of heavy PAH contamination (e.g. Rothermich et al. 2002, Bach et al. 2005), which is not the case for the pristine sediment we investigated.

The measurements of pyrene mineralization potential were performed under oxic conditions and the low initial rate of pyrene mineralization in the bulk sediment indicates that the bacteria from the reduced bulk sediment were less adapted to oxic conditions when compared with the bacteria from oxidized sediments, and that the abundances of aerobic pyrene-degrading bacteria were low. However, mineralization rates increased when the reduced sediment was exposed to oxygen. After $>1 \mathrm{wk}$, rates approached, but never equalled, that of oxidized sediments, presumably due to the establishment of a community of aerobic bacteria that could degrade pyrene. These results provide insights into the potential importance of bioturbation for pyrene degradation in bulk sediments. Temporary or short-term $(<1 \mathrm{wk})$ oxygenation of the bulk sediment is not likely to enhance pyrene degradation significantly. For example, establishment of permanent or semi-permanent burrows in bulk sediments should enhance degradation rates, while sporadic oxygenation of bulk sediments, e.g. due to the passage of errant polychaetes, will not have much of an effect.

The pyrene mineralization rates in sediment with Nereis diversicolor and without worms were almost constant throughout the experimental period, whereas mineralization rate decreased over time in sediment inhabited by Arenicola marina. The explanation for the 
decreasing pyrene mineralization rates is probably related to the decreased pyrene bioavailability in oxidized sediments, which was most pronounced in the presence of $A$. marina. Since PAH degradation in oxic environments is often limited by the amount of bioavailable substrate, the decreased pyrene bioavailability probably leads to the observed decreasing degradation rates.

The bioavailability of pyrene was determined as mineralization of ${ }^{14} \mathrm{C}$-pyrene after addition of a surplus of pyrene degrader cells (Semple et al. 2006) so that pyrene bioavailability was the limiting factor for mineralization. Two measures of bioavailability (Reichenberg \& Mayer 2006) can be inferred from these mineralization curves (Fig. 5). The initial mineralization rates are a relative measure of the ability of the environment to supply the bacteria with pyrene, i.e. a measure of the flux of substrate to the bacteria. In contrast, the maximum amount of pyrene mineralized is a measure of the bioaccessible amounts, i.e. the amounts that may potentially be mineralized over time. Both estimates are relative measures as some of the degraded pyrene is incorporated into the bacterial biomass. Intriguingly, both aspects of microbial pyrene bioavailability were strongly affected negatively by the presence of macrofauna and furthermore the effect of fauna seemed to be species specific (Table 4). In all treatments the bioavailability in surface sediments was higher than in bulk sediment. Generally, surface layers have a higher porosity compared with subsurface sediment (Kure \& Forbes 1997), leading to higher apparent diffusion coefficients, and hence, a potentially higher transfer of PAH to the bacteria (Liu et al. 2001). The presence of macrofauna did, however, decrease pyrene bioavailability in surface sediments compared with surface sediments of defaunated microcosms. Since both polychaetes defecate at the sediment surface, it is possible that gut passage of PAH-contaminated sediment may have reduced $\mathrm{PAH}$ bioavailability in the defecated sediment. Giessing \& Mayer (2004) showed that gut fluid from marine deposit-feeding polychaetes catalyzed oxidative coupling of pyrene metabolites to organic matter and subsequently decreased the bioavailability. The authors suggested that this reaction, which leads to covalent binding of PAHs, represents a sink for PAHs. This process may explain the macroinfauna-induced reduction in PAH bioavailability in surface sediment observed in this study. Microbial pyrene bioavailability in sediment from both Nereis diversicolor and Arenicola marina burrows was lower than in surface sediments, and the amounts of bioaccessible pyrene in burrows were also lower than in the surrounding bulk sediment. Most polychaetes, including A. marina and $N$. diversicolor, are known to produce mucus to stabilise their burrows, which leads to an increased organic carbon content of burrow lining and walls compared with other sediment compartments. Organic matter is one of the key factors controlling microbial pyrene bioavailability in soil and sediments, and increases in organic content may decrease PAH bioavailability substantially (e.g. Bogan \& Sullivan 2003). Whatever the mechanism, the polychaetes studied clearly decreased microbial PAH bioavailability in surface sediment and biogenic structures, which probably influenced the overall $\mathrm{PAH}$ degradation, especially in sediments with A. marina. Since the effects of macroinfauna on microbial $\mathrm{PAH}$ bioavailability have not previously been examined, it is not clear to what extent other polychaetes, or macroinfauna in general, affect microbial PAH bioavailability.

\section{CONCLUSIONS}

Nereis diversicolor and Arenicola marina stimulated microbial pyrene mineralization, but the effects of $A$. marina decreased over time. The mechanism responsible for this stimulation was most likely the increased oxygen availability caused by the construction and irrigation of macrofaunal burrows. Burrows and surface sediments were important sites for microbial pyrene mineralization, characterised by high mineralization potentials and high abundance of bacteria able to grow on pyrene, whereas the capacity for aerobic PAH mineralization in bulk sediment was low. The polychaetes, especially A. marina, decreased pyrene bioavailability to bacteria in surface and burrow sediments, and thereby reduced the otherwise stimulating effect of bioturbation on the mineralization of pyrene.

Acknowledgements. We thank Pernille Greve and Jan-Ole Nielsen for valuable technical assistance. This work was supported by a grant from the Danish Natural Sciences Research Council to O.A. and G.T.B. K.T. was supported by a $\mathrm{PhD}$ stipend from Roskilde University. This support is gratefully acknowledged.

\section{LITERATURE CITED}

Bach QD, Kim SJ, Choi SC, Oh YS (2005) Enhancing the intrinsic bioremediation of PAH-contaminated anoxic estuarine sediments with biostimulating agents. J Microbiol 43:319-324

Banta GT, Andersen O (2003) Bioturbation and the fate of sediment pollutants-experimental case studies of selected infauna species. Vie Milieu 53:233-248

Bauer JE, Kerr RP, Bautista MF, Decker CJ, Capone DG (1988) Stimulation of microbial activities and polycyclic aromatic hydrocarbon degradation in marine sediments inhabited by Capitella capitata. Mar Environ Res 25:63-84

Bogan BW, Sullivan WR (2003) Physicochemical soil parameters affecting sequestration and mycobacterial bio- 
degradation of polycyclic aromatic hydrocarbons in soil. Chemosphere 52:1717-1726

Bosma TMP, Middeldorp PJM, Schraa G, Zehnder AJB (1997) Mass transfer limitation of biotransformation: quantifying bioavailability. Environ Sci Technol 31:248-252

Boyd TJ, Montgomery MT, Steele JK, Pohlman JW, Reatherford SR, Spargo BJ, Smith DC (2005) Dissolved oxygen saturation controls $\mathrm{PAH}$ biodegradation in freshwater estuary sediments. Microb Ecol 49:226-235

Carmichael LM, Pfaender FK (1997) The effect of inorganic and organic supplements on the microbial degradation of phenanthrene and pyrene in soils. Biodegradation 8:1-13

Christensen M, Banta GT, Andersen O (2002) Effects of the polychaetes Nereis diversicolor and Arenicola marina on the fate and distribution of pyrene in sediments. Mar Ecol Prog Ser 237:159-172

Chung WK, King GM (1999) Biogeochemical transformations and potential polyaromatic hydrocarbon degradation in macrofaunal burrow sediments. Aquat Microb Ecol 19: 285-295

> Chung WK, King GM (2001) Isolation, characterization, and polyaromatic hydrocarbon degradation potential of aerobic bacteria from marine macrofaunal burrow sediments and description of Lutibacterium anuloederans gen. nov., sp. nov., and Cycloclasticus spirillensus sp. nov. Appl Environ Microbiol 67:5585-5592

> Coates JD, Woodward J, Allen J, Philp P, Lovley DR (1997) Anaerobic degradation of polycyclic aromatic hydrocarbons and alkanes in petroleum-contaminated marine harbor sediments. Appl Environ Microbiol 63:3589-3593

Eriksson M, Sodersten E, Yu ZT, Dalhammar G, Mohn WW (2003) Degradation of polycyclic aromatic hydrocarbons at low temperature under aerobic and nitrate-reducing conditions in enrichment cultures from northern soils. Appl Environ Microbiol 69:275-284

$>$ Forster S, Graf G (1995) Impact of irrigation on oxygen flux into the sediment-intermittent pumping by Callianassa subterranea and piston-pumping by Lanice conchilega. Mar Biol 123:335-346

Giessing AMB, Mayer LM (2004) Oxidative coupling during gut passage in marine deposit-feeding invertebrates. Limnol Oceanogr 49:716-726

Granberg ME, Hansen R, Selck H (2005) Relative importance of macrofaunal burrows for the microbial mineralization of pyrene in marine sediments: impact of macrofaunal species and organic matter quality. Mar Ecol Prog Ser 288: $59-74$

Huang WL, Weber WJ (1997) A distributed reactivity model for sorption by soils and sediments. 10. Relationships between desorption, hysteresis, and the chemical characteristics of organic domains. Environ Sci Technol 31:2562-2569

Johnsen AR, Karlson U (2005) PAH degradation capacity of soil microbial communities-Does it depend on PAH exposure? Microb Ecol 50:488-495

Johnsen AR, Bendixen K, Karlson U (2002) Detection of microbial growth on polycyclic aromatic hydrocarbons in microtiter plates by using the respiration indicator wst-1. Appl Environ Microbiol 68:2683-2689

Johnsen AR, Wick LY, Harms H (2005) Principles of microbial PAH-degradation in soil. Environ Pollut 133:71-84

Joner EJ, Corgie SC, Amellal N, Leyval C (2002) Nutritional constraints to degradation of polycyclic aromatic hydrocarbons in a simulated rhizosphere. Soil Biol Biochem 34: 859-864

Klee AJ (1993) A computer program for the determination of most probable number and its confidence-limits. J Microbiol Methods 18:91-98
Kristensen E (2000) Organic matter diagenesis at the oxic/ anoxic interface in coastal marine sediments, with emphasis on the role of burrowing animals. Hydrobiologia 426: $1-24$

Kristensen E, Jensen MH, Andersen TK (1985) The impact of polychaete (Nereis virens Sars) burrows on nitrification and nitrate reduction in estuarine sediments. J Exp Mar Biol Ecol 85:75-91

Kukkonen JVK, Landrum PF, Mitra S, Gossiaux DC, Gunnarsson J, Weston D (2003) Sediment characteristics affecting desorption kinetics of select PAH and PCB congeners for seven laboratory spiked sediments. Environ Sci Technol 37:4656-4663

Kure LK, Forbes TL (1997) Impact of bioturbation by Arenicola marina on the fate of particle-bound fluoranthene. Mar Ecol Prog Ser 156:157-166

Lei L, Khodadoust AP, Suidan MT, Tabak HH (2005) Biodegradation of sediment-bound PAHs in field contaminated sediment. Water Res 39:349-361

$>$ Liu B, Banks MK, Schwab P (2001) Effects of soil water content on biodegradation of phenanthrene in a mixture of organic contaminants. Soil Sediment Contam 10: 633-658

Mayer MS, Schaffner L, Kemp WM (1995) Nitrification potentials of benthic macrofaunal tubes and burrow wallseffects of sediment $\mathrm{NH}_{4}$ and animal irrigation behavior. Mar Ecol Prog Ser 121:157-169

McElroy AE, Farrington JW, Teal JM (1990) Influence of mode of exposure and the presence of a tubiculous polychaete on the fate of benz[a]anthracene in the benthos. Environ Sci Technol 24:1648-1655

McNally DL, Mihelcic JR, Lueking DR (1999) Biodegradation of mixtures of polycyclic aromatic hydrocarbons under aerobic and nitrate-reducing conditions. Chemosphere 38: 1313-1321

Meckenstock RU, Safinowski M, Griebler C (2004) Anaerobic degradation of polycyclic aromatic hydrocarbons. FEMS Microbiol Ecol 49:27-36

Neff JM (2002) Bioaccumulation in marine organisms: effect of contaminants from oil well produced water. Elsevier Science, Kidlington, Oxford

Nielsen OI, Gribsholt B, Kristensen E, Revsbech NP (2004) Microscale distribution of oxygen and nitrate in sediment inhabited by Nereis diversicolor: spatial patterns and estimated reaction rates. Aquat Microb Ecol 34:23-32

Nocentini M, Pinelli D (2001) Biodegradation of PAHs in aggregates of a low permeability soil. Soil Sediment Contam 10:211-226

Papaspyrou S, Gregersen T, Kristensen E, Christensen B, Cox RP (2006) Microbial reaction rates and bacterial communities in sediment surrounding burrows of two nereidid polychaetes (Nereis diversicolor and Nereis virens). Mar Biol 148:541-550

$>$ Reichenberg F, Mayer P (2006) Two complementary sides of bioavailability: accessibility and chemical activity of organic contaminants in sediments and soils. Environ Toxicol Chem 25:1239-1245

Reise K (1981) High abundance of small zoobenthos around biogenic structures in tidal sediments of the Wadden Sea. Helgol Meersunters (Helgol Mar Res) 34:413-425

Rockne KJ, Strand SE (1998) Biodegradation of bicyclic and polycyclic aromatic hydrocarbons in anaerobic enrichments. Environ Sci Technol 32:3962-3967

Roslev P, Iversen N, Henriksen K (1998) Direct fingerprinting of metabolically active bacteria in environmental samples by substrate specific radiolabelling and lipid analysis. J Microbiol Methods 31:99-111 
Rothermich MM, Hayes LA, Lovley DR (2002) Anaerobic, sulfate-dependent degradation of polycyclic aromatic hydrocarbons in petroleum-contaminated harbor sediment. Environ Sci Technol 36:4811-4817

Semple KT, Dew NM, Doick KJ, Rhodes AH (2006) Can microbial mineralization be used to estimate microbial availability of organic contaminants in soil? Environ Pollut

Editorial responsibility: Rutger de Wit,

Montpellier, France
140:164-172

Timmermann K, Banta GT, Glud RN (2006) Linking Arenicola marina irrigation behaviour to oxygen transport and dynamics in sandy sediments. J Mar Res 64:915-938

Wenzhofer F, Glud RN (2004) Small-scale spatial and temporal variability in coastal benthic $\mathrm{O}_{2}$ dynamics: effects of fauna activity. Limnol Oceanogr 49:1471-1481

Submitted: June 6, 2007; Accepted: October 25, 2007

Proofs received from author(s): December 18, 2007 